This is an electronic reprint of the original article. This reprint may differ from the original in pagination and typographic detail.

Author(s): Ojala, Arto; Isomäki, Hannakaisa

Title: $\quad$ Entrepreneurship and small businesses in Russia: A review of empirical research

Year: $\quad 2011$

Version:

Please cite the original version:

Ojala, A., \& Isomäki, H. (2011). Entrepreneurship and small businesses in Russia: A review of empirical research. Journal of Small Business and Enterprise Development, 18(1), 97-119. https://doi.org/10.1108/14626001111106451

All material supplied via JYX is protected by copyright and other intellectual property rights, and duplication or sale of all or part of any of the repository collections is not permitted, except that material may be duplicated by you for your research use or educational purposes in electronic or print form. You must obtain permission for any other use. Electronic or print copies may not be offered, whether for sale or otherwise to anyone who is not an authorised user. 


\title{
Entrepreneurship and small businesses in Russia: A review of empirical research
}

\section{Arto Ojala and Hannakaisa Isomäki University of Jyväskylä}

\begin{abstract}
Purpose - Entrepreneurship and small businesses in Russia have been of academic interest for over fifteen years. This paper brings together current knowledge concerning the phenomenon, and suggests further directions for research.
\end{abstract}

Design/methodology/approach - The study consists of a systematic review of forty-eight refereed empirical articles on entrepreneurship and small businesses in Russia.

Findings - From the articles reviewed it appears that entrepreneurs in Russia use non-material resources to overcome the financial and institutional obstacles which still seem to afflict the market. However, theoretical and methodological issues are, in many cases, poorly reported and this undermines the scientific rigor of the studies they report.

Research limitations/implications - Because of the wide scope of the studies reviewed the results included here provide somewhat broad-brush descriptions of the phenomenon. However, we believe that the findings are valuable for an understanding of the current situation for entrepreneurship and small businesses in Russia. The findings may also stimulate more in-depth research in this increasingly important topic. 
Originality/value - To the best of our knowledge, no literature review on this topic has previously been published in academic journals.

Keywords Entrepreneurship, SME, Russia, literature review, small firms, transition economy

Paper type Literature review

\section{Introduction}

Entrepreneurship and small businesses started to emerge in the Soviet Union after the economic reconstruction that took place in the late 1980s and at the beginning of the 1990s. The changes in the Soviet system led to the privatization of government-owned companies and created new possibilities for individuals to launch entrepreneurial activities (Ageev et al., 1995; Hisrich and Grachev, 1993; McCarthy et al., 1993). The changing situation gave an impetus to academic research related to entrepreneurship and small businesses in the former Soviet Union and in today's Russia. Research related to this topic is of real value, since it increases our understanding of entrepreneurial activities in transitional countries adapting to a free market economy. In a practical sense, it may also help local firms to develop their operations by revealing opportunities and constraints in the market. For foreign firms, a better understanding of entrepreneurship and small businesses in Russia may make it possible to develop new strategies for survival in the Russian market and for cooperation with Russian firms. However, although changes in Russian government policy and in the economic environment have led to expectations of increasing 
entrepreneurial activity (Seawright et al., 2008), entrepreneurship and small businesses in Russia lag behind the leading transitional countries in Eastern Europe (Kihlgren, 2003).

Now that entrepreneurship and small businesses in Russia have been of academic interest for over fifteen years, it is time to gather together current knowledge on the phenomenon and to suggest further directions for research. This is all the more important in view of the fragmented nature of the literature, mainly due to the wide scope of the phenomenon. Hence, the objective of this paper is to conduct a systematic review of the empirical literature related to entrepreneurship and small businesses in Russia.

In this review, we aim to answer the following questions: What is the current state of knowledge concerning entrepreneurship and small businesses in Russia? What kinds of theories and methodologies have been applied in studies related to this phenomenon? How should entrepreneurship and small businesses in Russia be studied in the future? In our analysis, the main points of interest will be the factors hindering or fostering entrepreneurship and small businesses in Russia. In addition, we shall evaluate how these factors have changed during the seventeen-year period covered in the review.

The study is organized as follows: first of all, we shall outline our methodology (for selecting the relevant literature, and for analyzing the studies selected). Thereafter, we shall present the findings from the review in two sub-sections: (i) research topics of the studies included, plus their main findings, (ii) theoretical frameworks and methodology of the studies included. Finally, we shall propose further directions for research, and provide a general summary of the literature. 


\section{Methodology of this review}

The first real entrepreneurial opportunities did not emerge in the former Soviet Union until the beginning of the 1990s (Hisrich and Grachev, 1995), hence this review focuses only on the period following the collapse of the Soviet Union in 1991. Although entrepreneurship and small businesses can be seen as different fields of study, there is still a high degree of overlap, and the literature in these fields focuses on fairly similar issues.

In the review process, we adopted the basic principles of a systematic review as recommended by e.g. Pittaway and Cope (2007) and Tranfield et al. (2003), namely (1) planning the review, (2) conducting the review, and (3) reporting and dissemination. We first conducted a keyword search based on the scope of the study, the literature, and the discussion of the authors in the main electronic databases (EBSCO host, Emerald, JSTOR, Inderscience, ISI Web of Knowledge, ProQuest, ScienceDirect, Springer, and Wiley/Blackwell). We used the keywords "Russia", "Moscow", and "St. Petersburg" with a combination of the following keywords: entrepreneurship, entrepreneurial, small business, small firms, SMEs. These keywords had to occur in the title, as keywords, and/or in the abstract section of the articles in the databases. Whenever we found a candidate article in a database, the following criteria were used to assess its eligibility for the full review: (1) published between 1991 and 2009; (2) published in English in an academic, peer-reviewed journal; (3) focusing on entrepreneurship or small businesses in Russia, and (4) empirical in nature, indicating clearly how quantitative or qualitative methods were applied. Both of the authors of this paper double-checked all the articles included within the review, with a view to ensuring the accuracy of the findings.

Because the focus here is on empirical works with a well-defined methodology, some important contributions were excluded. For instance, this review does not include articles that 
used illustrative cases with a practical focus (e.g. Beamish, 1992; Hisrich and Grachev, 1993), secondary data without a clearly defined methodology (e.g. Astrakhan and Chepurenko, 2003; Kontorovich, 1999), or purely conceptual articles (e.g. Orlov, 2003; Rehn and Taalas, 2004). We also excluded articles where the Russian market was only one out of several markets examined (e.g. Johnson et al., 2000; Welter et al., 2004).

Altogether, we found 48 eligible empirical articles focusing on entrepreneurship and small businesses in Russia. The articles included were published between 1993 and 2009 in 34 academic journals, giving some idea of the wide scope of the phenomenon. Out of the articles, 19 were published in entrepreneurship journals, 11 in economics journals, 6 in management journals, and the remaining 12 articles in other social science journals. Eight of the articles were published in journals (American Economic Review, Entrepreneurship Theory \& Practice, Journal of Business Venturing, Journal of International Business Studies, and Journal of Small Business Management) ranked by the Financial Times as prestigious journals in the business field.

\section{Characteristics of the studies reviewed}

Table 1 summarizes the methodological approaches used in the studies reviewed, the research topics addressed in the studies, and the main findings of the studies.

[Table 1 about here] 


\subsection{Research topics of the studies reviewed, and findings of the studies}

The topics of the studies reviewed can be divided into eight groups (Table 1). The main interests of the papers were (i) the impact of institutional issues on entrepreneurship in Russia (14 articles), (ii) strategic issues related to firms in a transitional market (11 articles), (iii) psychological characteristics of Russian entrepreneurs (7 articles), and (iv) networks and social capital (6 articles). In the remainder of the papers reviewed, the aim of the study was related to (v) managerial styles and practices, (vi) financial issues, (vii) perceptions of entrepreneurship, and (viii) cultural issues. Below, we shall elaborate the research topics and findings in more detail.

(i) Fourteen of the papers were interested in institutional issues and in the impact of the transitional economy on entrepreneurship in Russia. These aspects were seen as important because entrepreneurs adapt their activities according to the opportunities and limitations set by the institutional environment (North, 1994). These particular studies focused on the institutional environment for entrepreneurship in Russia, the effect of governmental regulations on entrepreneurship and small businesses, informal entrepreneurship, and the impact of entrepreneurial activity on economic growth in Russia. Institutional issues related to entrepreneurship were also studied in their historical context and by comparing entrepreneurial activity in rural and urban areas. These studies on institutional changes and their impact on entrepreneurship found both positive and negative changes. At the macro-level, the changes were reported as very positive. However, several of these studies indicated that the unstable institutional situation, inconsistent regulations, and absence of business laws still inhibit entrepreneurial activities in Russia.

(ii) Eleven papers analyzed the strategic issues affecting entrepreneurs or small firms. As Barney (1991) argues, firms can be seen as a combination of various resources - physical, human, 
and organizational - that can provide important competitive advantages. In the papers reviewed, the main purpose was to study the resources of the Russian firms and to find out how these resources may impact on further growth and performance, the success of Russian entrepreneurs, and the difficulties faced by Russian entrepreneurs or small firms. The findings in the studies indicate that intellectual capital, including human and structural capital, is seen as the major determinant of the performance of small and innovative enterprises, and of their further success. The difficulties of Russian entrepreneurs and small firms were found to be related to the Russian government, difficulties with suppliers, financial problems, high interest rates, finding a good location, production constraints, and internationalization.

(iii) The psychological characteristics of Russian entrepreneurs were investigated in seven studies. These characteristics are important, as they can explain entrepreneurs' decision-making processes (Simon et al., 2000), opportunity recognition (Shane and Venkataraman, 2000), locus of control (Perry, 1990), and other aspects. The studies reviewed here were interested in the psychological characteristics of Russian entrepreneurs and possible differences between Russian entrepreneurs and entrepreneurs from other countries. These comparisons were made mainly with entrepreneurs from the U.S., or between entrepreneurs and non-entrepreneurs. The findings indicated that Russian entrepreneurs have a lower education level than their U.S. counterparts. Russian new ventures used more of their own capital, had fewer earlier entrepreneurial experiences, and were more likely to be in the service sector than U.S. entrepreneurs. However, the studies also indicated that the personal characteristics of Russian entrepreneurs are rather similar to those of U.S. entrepreneurs.

(iv) Entrepreneurs' social capital and networks in Russia were the main focus in six of the articles. Networks and social capital were regarded as very important for entrepreneurs, since relationships between entrepreneurs can be used in different ways, for purposes that create value 
for actors within the network (Adler and Kwon 2002; Nahapiet and Ghoshal 1998). Burt (1992) in fact claims that social capital, rather than financial or human capital, is the most significant factor contributing to competitive advantages for firms. In the context of Russia, the main interest of these studies was related to how entrepreneurs' networks affect the start-up phase, financial performance, and investment decisions by venture capitalists. The findings revealed that social networks are important for entrepreneurial opportunities because persons whose relatives or friends are entrepreneurs have a greater chance of becoming entrepreneurs. This was argued to be important in transitional markets where the risk for new market entries is high. It was also found that Russian entrepreneurs were satisfied with their existing networks. This was indeed the reason why they did not actively form new relationships: it is more effective and less risky to maintain existing networks as long as they provide valuable resources.

(v) The managerial styles and practices of entrepreneurs were studied in three of the articles reviewed. This was seen as important because leadership styles have a direct impact on a firm's performance (Bass, 1990). The focus of these studies was on leadership styles, decision making processes, differences in the leadership styles of entrepreneurs and managers in Russia, and the development of managerial practices in small businesses in Russia. The findings in this group indicated that Russian entrepreneurs were likely to use their peers rather than their subordinates in collective decision making. It was also found that entrepreneurs exhibited inspirational and charismatic leadership behavior, whereas managers of large firms had a more passive and laissezfaire leadership style. The studies also indicated that managers in Russia adapt their management practices to changes in the business environment in which they operate.

(vi) Three of the studies reviewed focused on the financial resources of entrepreneurs and small firms in Russia. This topic was seen as important because financial resources have an important role in establishing firms and expanding businesses (Gratchev and Bobina, 2001). The 
studies investigated the credit market arrangements and the role of non-financial firms as the source of capital for small firms in Russia; they looked at shortcomings in credit markets, the security of property rights, and the financial resources of new ventures in the Russian market. The studies in this group argued that younger firms face higher information costs than is the case with established firms, and that their expansion is more related to the internal funding available. The findings also suggested that Russian financial markets are actually more developed than is typically assumed, and that there was a positive shift in the Russian economy in 2000 which created new financing opportunities for new ventures and SMEs.

(vii) Three of the studies focused on Russians' perceptions of entrepreneurship. Because the intentions of people impact on a particular behavior, these intentions are important in the decision to become an entrepreneur (Bird, 1988). The studies in this category were interested in the attitudes of entrepreneurs, managers, and students toward enterprise culture in Russia, and the issues influencing students' choices between entrepreneurial careers and employment in organizations. The findings revealed that among Russian students attitudes, subjective norms, and perceived behavioral control have a significant role in the choice of becoming an entrepreneur factors that would indicate a good potential for entrepreneurship in Russia. It was also found that young people in Russia have a more enterprising culture.

(viii) Finally, only one of the studies focused on cultural issues, revealing differences in work-related values between entrepreneurs and non-entrepreneurs in Russia and Georgia. Cultural values are of interest because these values have an effect on entrepreneurial behavior and innovativeness (Shane, 1993). The findings indicated that non-entrepreneurs differed from entrepreneurs in three of Hofstede's five cultural dimensions, with entrepreneurs in some cases being similar to managers and in other cases similar to employees. It was suggested that distinctions between entrepreneurs and non-entrepreneurs are not as useful as commonly assumed. 


\subsection{Theoretical frameworks and methodological approaches in the studies reviewed}

This sub-section will cover the theoretical frameworks applied in the studies reviewed, and elaborate the data collection methods, sample sizes, and key informants. It will then look at the sizes of the firms and target industries included in the studies. Finally, there will be consideration of the analytical approaches and types of research that the studies applied.

\subsubsection{Theoretical frameworks}

The studies used a broad range of theoretical frameworks. This is unsurprising, given the various perspectives taken on the entrepreneurship and small businesses in Russia. However, only a few of the studies can be categorized as theoretical in a strict sense, and there was great variation in the extent to which theories or frameworks were rigorously applied or clearly defined. The commonly used background theories consisted of the network/social capital theory (4 articles), the resource-based view (4 articles), and Hofstede's cultural dimensions (2 articles). In some of the papers reviewed, the theoretical background was constructed through a combination of different theories or frameworks. It is important to note that altogether 17 studies were without any background theory or theoretical framework that could be used for empirical investigation. These studies were somewhat descriptive, lacking well-argued theoretical underpinnings. 


\subsubsection{Data collection method, sample size, and key informants}

Altogether 38 out of the 48 studies reviewed used a personally administered survey for data collection. In these studies, research assistants, trained students, survey firms, or trained volunteers personally delivered and collected questionnaires, or gathered data by interviewing informants. This kind of data collection method was found to be more effective in Russia where traditional mail surveys do not generate a sufficient sample size. This was reported to be due to inexperience and to a resistant attitude towards surveys (see e.g. Gratchev and Bobina, 2001; Jumpponen et al., 2008; Sommer et al., 2000), the latter feature being mainly due to the desire of firms to protect their sensitive information from the mafia and from government (Bruton and Rubanik, 1997). Secondary data from various sources was used for empirical analyses in five of the studies, in-depth interviews were used in four qualitative studies, and a traditional survey method was used in only one study.

The final sample size in the quantitative studies reviewed varied between 15 and 2590, and in the qualitative studies from 1 case firm to 40 informants. Unfortunately, most of the studies did not provide information on the response rate. In those studies where it was mentioned, the response rate varied between 45 percent and 95 percent. However, because a personallyadministered survey method was used in many articles, we can assume that the response rate was fairly high. In the study by Gratchev and Bobina (2001) in which the authors used a traditional survey method, the response rate was only 26 percent.

The informants used for the studies reviewed came from different kinds of groups, including (mainly) entrepreneurs, managers, owners, students, and employees. Two or more informant groups (included according to the research purpose of the study) were used in 17 studies. The largest individual informant group was that of entrepreneurs, a group used in 10 studies. 
Altogether, 10 of the articles reviewed did not provide information on the informants used in the studies they reported. In these thirteen studies, the author(s) either used secondary data or else the informants were not reported.

\subsubsection{Firm size and industry in the studies reviewed}

Data on the size of the firm used in the analysis was missing in several studies, or else it was defined rather broadly. Altogether, 8 of the studies used firms of various sizes, covering small and large firms. In other studies, where information on the number of employees was available, it was from 0 to 1540 employees. Altogether, 28 of the studies reviewed did not give information on the sizes of the firms covered. Some of the studies used students as one of the groups of informants and, hence, could not report the firm size (see e.g. Tkachev and Kolvereid, 1999).

Information on the target industry was provided in 25 studies. However, 9 out of these 25 studies were referred to as being cross-industrial or as covering more than 5 industries. In

addition, 3 of the studies mentioned the main industries covered, but did not give exclusive information on other industries involved (Ardichvili and Gasparishvili, 2003; Frye and Shleifer, 1997; McCarthy et al., 1993). Altogether, only 14 studies gave detailed information on the target industries, and only 7 studies focused on a single industry.

\subsubsection{Analytical approaches and types of research in the studies reviewed}

A quantitative research approach was applied in a total of 44 papers. However, the level of the quantitative analyses varied from tabular analysis (see e.g. Hisrich and Grachev, 1995) to regression analysis (see e.g. Batjargal, 2007a). A qualitative approach was taken in only 4 papers 
(Bruton and Rubanik, 1997; Kapustkina et al., 2008; Molz et al. 2009; Rogers, 2006). The reasons for selecting a particular analytical approach were poorly reported in most of the studies.

Altogether, 27 of the studies reviewed were descriptive in nature. These studies used statistical analyses to identify patterns or trends in the data. In 17 studies, the type of research was confirmatory, meaning that certain hypotheses were statistically verified. Only the 4 qualitative papers used an exploratory research approach aimed at theory building.

\section{Discussion}

In this section, on the basis of the articles reviewed, we shall first assess the current state of knowledge concerning entrepreneurship and small businesses in Russia. Thereafter, we shall discuss the theories, models, and methodologies applied in the papers reviewed.

\subsection{Current state of knowledge concerning entrepreneurship and small businesses in Russia}

Most of the 48 articles reviewed for this study focused on institutional issues in Russia, strategic issues in a transitional market, the social capital of entrepreneurs, and the psychological characteristics of Russian entrepreneurs. The first three topics received attention because they can generate new knowledge on how institutional changes and instability impact on entrepreneurs and small firms, how entrepreneurs and small firms develop their strategies to overcome problems in the transitional Russian market, and how resources acquired though networks can be used to compensate for a lack of other resources in the market. The psychological characteristics of Russian entrepreneurs received attention because the authors were interested in possible differences between entrepreneurs in Russia and other countries. 
From the papers examined it appeared that entrepreneurship as a phenomenon and the psychological characteristics of entrepreneurs are fairly similar in Russia to what they are in other countries and especially among American entrepreneurs. The differences are mainly related to environmental differences and to the education level in the countries compared, not in actual behavior. Given the similarities in these respects, it would appear that the slow development of small businesses in Russia is more related to the business environment in which entrepreneurial activities are conducted. Thus, more generally, this finding indicates that the business environment in a certain country inhibits entrepreneurship more than the psychological characteristics of entrepreneurs.

Studies related to the market environment and actions taken by entrepreneurs have mainly considered the factors fostering and hindering entrepreneurship in Russia. The findings here indicate that the performance and growth potential of Russian small firms is based mainly on their social capital and network relationships, their intellectual capital, and the human-based resources available. These "non-material" resources are important in fostering entrepreneurship and overcoming obstacles in the transitional market. Most of the obstacles confronting entrepreneurship and small businesses are related to financial problems and governmental restrictions. Although some studies indicated positive changes in Russia for entrepreneurship and small businesses at the macro-level, it seems that the business environment there is still highly unstable. For instance, the studies reviewed found that growth is still restricted by environmental and institutional instability, high interest rates, inconsistent regulations and laws, the mafia, and corruption. This has also led to a high amount of informal, unregistered entrepreneurs in Russia. This finding also indicates that in countries with an unstable institutional environment, the amount of entrepreneurship might be much higher than the formal registers indicate (see also William and Round, 2008, 2009; William et al., 2006). 


\subsection{Theories, models, and methodologies applied in the studies reviewed}

Because entrepreneurship and small businesses are diverse and multi-disciplinary, the studies reviewed used a wide range of different models, theories, frameworks, and combinations of these. However, the theoretical richness of the papers reviewed was, in many cases, relatively low, and in fact, only a few of the studies could be regarded as highly theoretical. In addition, the presentation of the various theories and models applied was very often inadequately reported. It is also important to note that altogether seventeen studies were without any well-argued theoretical framework at all. Thus, researchers in the field should pay more attention to the theoretical frameworks applied in empirical analyses, since this will be the only way to improve theoretical understanding of the phenomenon.

It is also important to note that, in many cases, methodological issues were poorly reported. Most of the studies did not give information on the response rate in the data collection. In many papers, information on informants, firm size, and/or target industry was missing or loosely defined. The reasons for the selection of a certain research approach were also poorly reported, making many of the papers somewhat deficient in this respect. This presents a challenge, not only to authors in the field, but also to the reviewers and editors in academic journals, in relation to improving the scientific rigor of published papers.

On the basis of papers reviewed, it seems that out of all data collection methods, personally administered data collection works best in Russia, where the response rate for traditional surveys is very low. For this reason, 38 out of the 48 studies reviewed applied surveys that were personally administered. However, this left other data collection methods with a much smaller share. For instance, the qualitative case study method (see e.g. Yin, 1994) was used only in four 
exploratory studies, although it can provide detailed information, including information on the cause-and-effect relationships of entrepreneurial activities in Russia. Through the use of the qualitative case study method, researchers could get a better and deeper understanding of the phenomenon, with a focus on "how" and "why" questions. Thereafter, these findings could be tested, validated, and generalized using quantitative research methods. In the literature reviewed, it seems that authors collected the data using ready-made survey questions that do not reveal issues beyond the scope of the questionnaire. Hence, open interviews could give a much wider understanding of the phenomenon and the reasons behind a certain behavior.

\section{Conclusions}

It seems that there have not been many changes in the factors fostering and hindering entrepreneurship and small businesses in Russia during the seventeen-year period covered in the articles reviewed. McCarthy et al. (1993) argued that the Russian government is the major factor inhibiting business. In line with this, more recent studies by Aidis et al. (2008) and Molz et al. (2009) revealed fairly similar results, indicating that the institutional environment creates barriers for business and entrepreneurship. This conclusion is also supported by the study of Zhuplev and Shtykhno (2009) indicating that obstacles and problems for small business remains fairly similar during the fifteen-year period studied. Similarly, the factors fostering entrepreneurship and small businesses have remained fairly constant over the time period covered. For instance, skillful employees and network relationships (social capital) are seen as the major sources for overcoming institutional weaknesses and other problems in the market. The overall picture is that the same factors fostering and hindering entrepreneurship and small businesses can be found in 
the studies, regardless of the year of publication. These findings suggest that there have been very few changes in Russia's business environment since the collapse of the Soviet Union.

Although the studies related to entrepreneurship and small businesses in Russia examined highly important research areas, there are topics for further research. First of all, because institutions and the business environment in Russia seem to be the most important inhibitors for entrepreneurship and small business, it is important to study the interaction between entrepreneurs and institutions. As North $(1994,361)$ pointed out, "If institutions are the rules of the game, organizations and their entrepreneurs are the players." Hence it is important to know how successful entrepreneurs play this game - in other words, establish and maintain relationships with different institutions to facilitate their growth. In these studies, researchers should focus on informal constraints (e.g. norms of behavior), since these change much more slowly than formal constraints (e.g. laws and rules), and are based on interpretations of formal rules (see North, 1994).

Secondly, comparative studies that focus on changes in institutional environment are important when one is seeking to determine why entrepreneurship and small businesses in Russia lag behind other transitional markets. Such studies would provide knowledge on how the institutional environment in Russia should be developed to make it more favorable to entrepreneurship. In addition, it is important to convince political decision makers about the importance of entrepreneurship in Russia for the generation of economic growth.

Thirdly, more studies are needed on entrepreneurship training and how it should be implemented in Russia. As earlier studies have confirmed, it is important to adapt training programs to local cultural values and ways of doing business (Ojala and Heikkilä, in press), since Western practices cannot be applied indiscriminately to the Russian business environment 
(Ardichvili et al., 1998). By taking into account entrepreneurs' specific needs and problems, these studies could benefit organizations implementing training programs for entrepreneurs.

Fourthly, it should be noted that the internationalization of Russian small enterprises was the focus of attention in only some of the studies reviewed. Moreover, the studies that did focus on internationalization concentrated mainly on the obstacles encountered in the internationalization process of Russian small firms. More studies are needed in relation to the foreign market selection and entry modes applied by Russian small firms in different countries and sectors. Studies of that kind could help Russian entrepreneurs to develop their international activities by revealing best practices in foreign markets. It is also very important to study the inward internationalization activities (Welch and Luostarinen, 1993) of Russian small enterprises, due to the fact that Russia is well known for its offshore outsourcing in various industry sectors (see e.g. Pries-Heje et al., 2005). Studies related to the inward internationalization and offshore outsourcing activities of Russian small firms could generate important knowledge for, on the one

hand, foreign firms that are looking for Russian firms to provide them with offshore outsourcing services, and on the other hand, for Russian small firms that are able to implement offshore outsourcing activities. This could also help to increase the number of offshore outsourcing firms, and consequently lead to a more general increase in entrepreneurship in Russia. The inward internationalization of Russian small firms would also increase the potential for outward internationalization, as these firms would have to learn to deal with foreign firms.

\section{Summary}

This paper seeks to advance knowledge of the current state of entrepreneurship and small businesses in Russia. It reports on a review of forty-eight empirical studies in the field. The 
studies as a whole indicated that entrepreneurs in Russia use non-material resources to overcome the financial and institutional obstacles that still seem to afflict the market. The review further revealed the wide range of background theories and methodologies that have been used to study the phenomenon of entrepreneurship and small businesses in Russia. However, in many of the articles examined, theoretical and methodological circumstances were poorly reported, decreasing the scientific quality of the studies in question. Finally, this paper presents considerations that may advance future research.

The present study is not without its limitations. Total coverage of all the empirical articles in this specific field of study may not have been achieved, despite the use of numerous databases and a wide variety of key words. Nevertheless, it seems reasonable to assume that the review process did cover a major proportion of the academic articles in the field. Due to the wide range of the phenomenon and the different reporting styles in the forty-eight articles reviewed, identifying the essential information needed for this study was often demanding. The assessment of the theoretical frameworks and methodological concerns was particularly difficult. In addition, because of the wide scope of the studies, the results included here provide somewhat broad-brush descriptions of the phenomenon. However, we would hope that further studies could benefit from the more general findings presented here and focus on more specific issues, for example by comparing the development of entrepreneurship in Russia with the situation in other transition economies.

\section{References}

Adler, P.S. and Kwon, S-W. (2002), "Social capital: Prospects for a new concept", Academy of Management Review, Vol. 27 No. 1, pp. 17-40. 
Ageev, A.I., Gratchev, M.V. and Hisrich, R.D. (1995), "Entrepreneurship in the Soviet Union and Post-Socialist Russia”, Small Business Economics, Vol. 17 No. 5, pp. 365-376.

Aidis, R., Estrin, S. and Mickiewicz, T. (2008), "Institutions and entrepreneurship development in Russia: A comparative perspective", Journal of Business Venturing, Vol. 23 No. 6, pp. 656672.

Ardichvili, A. (2001), "Leadership Styles of Russian Entrepreneurs and Managers”, Journal of Developmental Entrepreneurship, Vol. 6 No. 2, pp. 169-188.

Ardichvili, A., Cordozo, R.N. and Gasparishvili, A. (1998), "Leadership Styles and Management Practices of Russian Entrepreneurs: Implications for Transferability of Western HRD Interventions", Human Resource Development Quarterly, Vol. 9 No. 2, pp. 145-155.

Ardichvili, A. and Gasparishvili, A. (2003), "Russian and Georgian Entrepreneurs and Nonentrepreneurs: A Study of Value Differences”, Organizational Studies, Vol. 24 No. 1, pp. 29-46.

Astrakhan, I. and Chepurenko, A. (2003), "Small business in Russia: any prospects after a decade?", Futures, Vol. 35, pp. 341-359.

Barney, J. (1991), "Firm resource and sustained competitive advantage", Journal of Management, Vol. 17 No. 1, pp. 99-120. 
Bass, B.M. (1990), "From Transactional to Transformational Leadership: Learning to Share the Vision”, Organizational Dynamics, Vol. 18 No. 3, pp. 32-43.

Batjargal, B. (2003), "Social Capital and Entrepreneurial Performance in Russia: A Longitudinal Study", Organization Studies, Vol. 24 No.4, pp. 535-556.

Batjargal, B. (2005), "Entrepreneurial versatility, resource and firm performance in Russia: a panel study", International Journal of Entrepreneurship and Innovation Management, Vol. 5 No. 3-4, pp. 284-297.

Batjargal, B. (2006), “The dynamics of entrepreneurs' networks in a transitional economy: the case of Russia", Entrepreneurship \& Regional Development, Vol. 18 No. 4, pp. 305-320.

Batjargal, B. (2007a), “Comparative Social Capital: Networks of Entrepreneurs and Venture Capitalists in China and Russia", Management and Organization Review, Vol. 3 No. 3, 397-419.

Batjargal, B. (2007b), "Network triads: transitivity, referral and venture capital decisions in China and Russia”, Journal of International Business Studies, Vol. 38 No. 6, pp. 998-1012.

Beamish, P. (1992), “Russki Adventures”, European Management Journal, Vol. 10 No. 4, pp. 465-476.

Berkowitz, D. and DeJong, D.N. (2005), "Entrepreneurship and Post-socialist Growth", Oxford Bulletin of Economics and Statistics, Vol. 67 No. 1, pp.25-46. 
Berkowitz, D. and Jackson, J.E. (2006), "Entrepreneurship and the evolution of income distributions in Poland and Russia", Journal of Comparative Economics, Vol. 34 No. 2, pp. 338356.

Bird, B. (1988), "Implementing Entrepreneurial Ideas: The Case for Intention", Academy of Management Review, Vol. 13 No. 3, pp. 442-453.

Bruton, G.D. and Rubanik, Y. (1997). "High technology entrepreneurship in transitional economies: the Russian experience", Journal of High Technology Management Research, Vol. 8 No. 2, pp. 213-223.

Bruton, G.D. and Rubanik, Y. (2002), "Resources of the firm, Russian high-technology startups, and firm growth", Journal of Business Venturing, Vol. 17, pp. 553-572.

Burt, R.S. (1992), Structural Holes, Harvard University Press, Cambridge, MA.

Cook, L.D. (1999), “Trade credit and bank finance: financing small firms in Russia”, Journal of Business Venturing, Vol. 14 No. 5-6, pp. 493-518.

Djankov, S., Roland, G., Miguel, E., Zhuravskaya, E. and Qian, Y. (2005), "Who are Russia's entrepreneurs?", Journal of the European Economic Association, Vol. 3 No. 2-3, pp. 587-597. 
Djankov, S., Roland, G., Qian, Y. and Zhuravskaya, E. (2006), "Entrepreneurship in China and Russia compared", Journal of the European Economic Association, Vol. 4 No. 2-3, pp. 352-365.

Frye, T. and Shleifer, A. (1997), "The Invisible Hand and the Grabbing Hand", American Economic Review, Vol. 87 No. 2, pp. 354-358.

Gratchev, M.V. and Bobina, M.A. (2001), "Financial resources for new business in Russia: desirable vs available", Venture Capital, Vol. 3 No. 3, pp. 267-274.

Green, R., David, J., Dent, M. and Tyshkovsky, A. (1996), ”The Russian entrepreneur: a study of psychological characteristics", International Journal of Entrepreneurial Behaviour \& Research, Vol. 2 No. 1, pp. 49-58.

Gunasekaran, A., Opanasenko, J. and Yli-Olli, P. (2001), ”Managing operations in small and medium sized Russian enterprises: an empirical research", International Journal of Manufacturing Technology and Management, Vol. 3 No. 4/5, pp. 375-392.

Hartarska, V. and Gonzalez-Vega, C. (2006), “What Affects New and Established Firm's Expansion? Evidence from Small Firms in Russia”, Small Business Economics, Vol. 27, pp. 195206.

Hisrich, R.D. and Grachev, M.V. (1993), “The Russian Entrepreneur”, Journal of Business Venturing, Vol. 8, pp. 487-497. 
Hisrich, R.D. and Grachev, M.V. (1995), "The Russian entrepreneur: characteristics and prescriptions for success", Journal of Managerial Psychology, Vol. 10 No. 2, pp. 3-9.

Johnson, S., McMillan, J. and Woodruff, C. (2000), "Entrepreneurship and the ordering of institutional reform: Poland, Slovakia, Romania, Russia and Ukraine compared", Economics of Transition, Vol. 8 No. 1, pp. 1-36.

Jumpponen, J., Ikävalko, M. and Pihkala, T. (2008), "Management and change in turbulent times: How Russian Small Business Managers perceive the development of their business environment?", Journal of Business Economics and Management, Vol. 9 No. 2, pp. 115-122.

Kalantaridis, C., Labrianidis, L. and Vassilev, I. (2007), "Entrepreneurship and institutional change in Post-socialist rural areas: Some evidence from Russia and the Ukraine", Journal for East European Management Studies, Vol. 12 No. 1, pp. 9-34.

Kapustkina, E., Sinyutin, M. and Veselov, Y. (2008), "A note on entrepreneurial trust in the Saint-Petersburg region of contemporary Russia”, International Journal of Entrepreneurship and Small Business, Vol. 6 No. 1, pp. 94-102.

Kaufmann, P.J., Welsh, D.H.B. and Bushmarin, N.V. (1995), "Locus of Control and Entrepreneurship in the Russian Republic”, Entrepreneurship Theory \& Practice, Vol. 20 No. 1, pp. 43-56. 
Kihlgren, A. (2003), "Small business in Russia - factors that slowed its development: an analysis", Communist and Post-Communist Studies, Vol. 36 No. 2, pp. 193-207.

Kim, B-Y. and Kang, Y. (2009), "The informal economy and the growth of small enterprises in Russia“, Economics of Transition, Vol. 17 No. 2, pp. 351-376.

Kontorovich, V. (1999), "Has new business creation in Russia come to a halt?", Journal of Business Venturing, Vol. 14 No. 5-6, pp. 451-460.

McCarthy, D.J., Puffer, S.M. and Shekshnia, S.V. (1993), “The Resurgence of an Entrepreneurial Class in Russia", Journal of Management Inquiry, Vol. 2 No. 2, pp. 125-137.

Molz, R., Tabbaa, I. and Totskaya, N. (2009), "Institutional Realities and Constraints on Change: The Case of SME in Russia”, Journal of East-West Business, Vol. 15, No. 2, pp. 141-156.

Nahapiet, J. and Ghoshal, S. (1998), "Social Capital, Intellectual Capital, and the Organizational Advantage", Academy of Management Review, Vol. 23 No. 2, pp. 242-266.

North, D.C. (1994), "Economic performance through time”, American Economic Review, Vol. 84 No. 3, pp. 359-368.

Ojala, A. and Heikkilä, J. (in press), "Entrepreneurship training for new ventures”, International Entrepreneurship and Management Journal. 
Orlov, A. (2003), "Prospects for the Development of Small Business in Russia", Problems of Economic Transition, Vol. 45 No. 11, pp. 59-68.

Perry, C. (1990), “After Further Sightings of the Heffalump”, Journal of Managerial Psychology, Vol. 5 No. 2, pp. 22-31.

Pissarides, F., Singer, M. and Svejnar, J. (2003), "Objectives and constraints of entrepreneurs: evidence from small and medium size enterprises in Russia and Bulgaria", Journal of Comparative Economics, Vol. 31, pp. 503-531.

Pittaway, L. and Cope, J. (2007), "Entrepreneurship Education: A Systematic Review of the Evidence”, International Small Business Journal, Vol. 25 No. 5, pp. 479-510.

Pries-Heje, J, Baskerville, R. and Hansen, G.I. (2005), “Strategy Models for Enabling Offshore Outsourcing: Russian Short-Cycle-Time Software Development”, Information Technology for Development, Vol. 11 No. 1, pp. 5-30.

Rehn, A. and Taalas, S. (2004), “'Znakomstva I Svyazi’ (Acquaintances and connections) -Blat, the Soviet Union, and mundane entrepreneurship", Entrepreneurship \& Regional Development, Vol. 16 No. 3, pp. 235-250.

Robinson, P.B., Ahmed, Z.U., Dana, L.P., Latfullin, G.R. and Smirnova, V. (2001), “Towards entrepreneurship and innovation in Russia", International Journal of Entrepreneurship and Innovation Management, Vol. 1 No. 2, pp. 230-240. 
Rogers, N. (2006), "Social Networks and the Emergence of the New Entrepreneurial Ventures in Russia”, American Journal of Economics and Sociology, Vol. 65 No. 2, pp. 295-312.

Safavian, M.S., Graham, D.H. and Gonzalez-Vega, C. (2001), "Corruption and Microenterprises in Russia", World Development, Vol. 29 No. 7, pp. 1215-1224.

Seawright, K.W., Mitchell, R.K. and Smith, J.B. (2008), "Comparative Entrepreneurial Cognitions and Lagging Russian New Venture Formation: A Tale of Two Countries”, Journal of Small Business Management, Vol. 46 No. 4, pp. 512-535.

Shane, S. (1993), "Cultural influences on national rates of innovation", Journal of Business Venturing, Vol. 8 No. 1, pp. 59-73.

Shane, S. and Venkataraman, S. (2000), "The promise of entrepreneurship as a field of research", Academy of Management Review, Vol. 26 No. 1, pp. 13-17.

Shirokova, G. (2009), "Organisational life-cycle: The characteristics of developmental stages in Russian companies created from scratch", Journal for East European Management Studies, Vol. 14 No. 1, pp. 65-85.

Simon, M., Houghton, S.M. and Aquino, K. (2000), "Cognitive biases, risk perception, and venture formation: How individuals decide to start companies", Journal of Business Venturing, Vol. 15 No. 2, pp. 113-134. 
Sommer, S.M., Welsh, D.H.B. and Gubman, B.L. (2000), “The Ethical Orientation of Russian Entrepreneurs", Applied Psychology: An International Review, Vol. 49 No. 4, pp. 688-708.

Stewart, Jr., W.H., Carland, J.C., Carland, J.W., Watson, W.E. and Sweo, R. (2003), "Entrepreneurial Dispositions and Goal Orientations: A Comparative Exploration of United States and Russian Entrepreneurs", Journal of Small Business Management, Vol. 41 No. 1, pp. 27-46.

Thelen, S. and Zhuplev, A. (2002), "Comparing Attitudes Toward Ethical Dilemmas in Small Business: Russia versus the United States”, Journal of East-West Business, Vol. 7 No. 4, pp. 2954.

Tkachev, A. and Kolvereid, L. (1999), "Self-employment intentions among Russian students", Entrepreneurship \& Regional Development, Vol. 11 No. 3, pp. 269-280.

Toppinen, A., Toivonen, R., Mutanen, A., Goltsev, V. and Tatti, N. (2007), "Sources of competitive advantage in woodworking firms of Northwest Russia", International Journal of Emerging Markets, Vol. 2 No. 4, pp. 383-394.

Tovstiga, G., Hamer, P.D., Popova, V.A., Efimov, I.P., Moskalev, S.V. and Bortnik, I.M. (2004), "Preparing Russian Small Innovative Enterprises for International Competitiveness: A Scoping Study”, Journal of International Entrepreneurship, Vol. 2 No. 1-2, pp. 89-108. 
Tovstiga, G. and Tulugurova, E. (2007), "Intellectual capital practices and performance in Russian enterprises", Journal of Intellectual Capital, Vol. 8 No. 4, pp. 695-707.

Tranfield, D., Denyer, D. and Smart, P. (2003), "Towards a Methodology for Developing Evidence-Informed Management Knowledge by Means of Systematic Review”, British Journal of Management, Vol. 14, pp. 207-222.

Tullar, W.L. (2001), "Russian Entrepreneurial Motive Patterns: A Validation of the Miner Sentence Completion Scale in Russia", Applied Psychology: An International Review, Vol. 50 No. 3, pp. 422-435.

Welch, L.S. and Luostarinen, R. (1993), "Inward-outward connections in internationalization", Journal of International Marketing, Vol. 1 No. 1, pp. 44-56.

Welter, F. Kautonen, T. Chepurenko, A., Malieva, E. and Venesaar, U. (2004), "Trust environments and entrepreneurial behavior - Exploratory evidence from Estonia, Germany and Russia”, Journal of Enterprising Culture, Vol. 12 No. 4, pp. 327-349.

Williams, C.C. and Round, J. (2008), "The hidden enterprise culture of Moscow: Entrepreneurship and off-the-books working practices", Journal of Developmental Entrepreneurship, Vol. 13 No. 4, pp. 445-462. 
Williams, C.C. and Round, J. (2009), "Evaluating informal entrepreneurs' motives: evidence from Moscow", International Journal of Entrepreneurial Behaviour \& Research, Vol. 15 No. 1, pp. 94-107.

Williams, C.C., Round, J. and Rodgers, J. (2006), "Beyond necessity- and opportunity-driven entrepreneurship: some case study evidence from Ukraine", Journal of Business and Entrepreneurship, Vol. 18 No. 2, pp. 22-34.

Yin, R.K. (1994), Case Study Research: Design and Methods, SAGE Publications, California.

Zhuplev, A., Kon'Kov, A. and Kiesner, F. (1998), "Russian and American Small Business: Motivations and Obstacles", European Management Journal, Vol. 16 No. 4, pp. 505-516.

Zhuplev, A. and Shtykhno, D. (2009), "Motivations and Obstacles for Small Business Entrepreneurship in Russia: Fifteen Years in Transition”, Journal of East-West Business, Vol. 15 No. 1, pp. 25-49. 
